\title{
Using in vitro tensile strength test to monitoring quality and effectiveness of suture in the oral environment
}

\author{
Hajar Lashab ${ }^{1,2^{*}}$, Brahim Benaji ${ }^{1,2^{*}}$, A. Sbitti ${ }^{1}$, Nabil Lahrache ${ }^{3}$, Mustapha Malha ${ }^{4},$. Bouchra Meddah ${ }^{2,3}$ and Rachida Ameziane ${ }^{5}$ \\ ${ }^{1}$ Biomedical Engineering and Pharmaceuticals Sciences Groupe Research - National Graduate School of Arts and Crafts \\ (ENSAM)- Mohammed V University Rabat - Morocco \\ ${ }^{2}$ Bio-pharmaceutical and Toxicology Analysis Laboratory- Drugs Sciences Center-Mohammed V University in Rabat - \\ Morocco \\ ${ }^{3}$ National quality control laboratory of drug -DMP- Ministry of Health - Rabat - Morocco \\ ${ }^{4}$ Thermal and Energy Research Center - Higher School of Technical Education, Mohammed V University in Rabat \\ ${ }^{5}$ Faculty of Dental Medicine, Mohammed V University in Rabat - Morocco
}

\begin{abstract}
Sutures are medical devices used in surgery. They serve as tissues stabilizers in contact with or near to the surgical site without compromising the healing process. They must keep their physical properties for the necessary time, in particular tensile strength. In view of the wide variety of references offered by all specialtys combined, which supply sutures with all materials described, whose use is indicated for all surgical procedures. The objective of this work is to evaluate the tensile strength of absorbable and non-absorbable sutures for a period of 10 to 28 days under conditions simulated by the oral route. 5 sutures materials were tested with a metric diameter of 1.5 and 4.The tensile strength test was used according to the protocol of the European Pharmacopoeia (Eur.Ph.9.5). 5 fragments of each material were measured before and after their immersion in Artificial Saliva (AS). In AS, the Polypropylene suture significantly maintained $(p=5 \%)$ its tensile strength compared to that of Polyamide. For absorbable sutures, a loss of more than $70 \%$ of their initial strength was marked on the $7^{\text {th }}$ day of immersion. In view of the results obtained, during oral surgical operations, the material of choice is in favor of Propylene.
\end{abstract}

Keyword. Medical device, Suture, Tensile strength, Artificial saliva, Monitoring.

\section{Introduction}

Surgery has continued to progress in recent years. Whether for therapeutic, aesthetic or tissue management purposes, post-surgical healing remains a key point common to all types intervention. Most surgical procedures require sutures, meeting specific criteria. The suture is a biomaterial device, natural or synthetic, used to ligate and bring the tissues together while ensuring the best possible healing [1]. The behavior of the different biomaterials used in various environments is based on a two-way mechanism: the effects of the biomaterial on the environment, as well as the effects of the environment on the biomaterial.

Various factors make suturing a different phenomenon in the oral environment compared to other parts of the body, due to the type of tissues, the constant presence of saliva, high tissue vascularity, as well as the functions related to speech, chewing, and swallowing. For this, the most suitable material is necessary. The suture should therefore generate a tissue reaction and a minimum tensile force. It must ensure non-capillarity, security of the knot and easy handling. [1]. The choice of the suture must be based on the optimum tensile strength, handling, penetration and glide, thus offering the practitioner ease of placement and realization of stitches while guaranteeing the preservation of the sutured tissues.

The wide variety of suture reference biomaterials marketed with different names, are indicated for all types of surgical procedures [2]. During the postoperative phase, the suture stabilizing the tissues in contact or near the surgical site, must not compromise the healing process. Indeed, it must keep during this time of contact its physical properties, in particular that of resistance allowing the maintenance of tissue coaptation.

The objective of our work is to simulate in vitro studies and the behavior of the suture for two reasons: on one hand, to determine and to predict its compatibility and its stability at the level of its site of use, and on the other hand to provide security to patients and propose a selection criterion for the clinician.

\section{Materials and methods}

\subsection{Suture sample}

5 suture biomaterials were chosen according to their use in dental surgery and whose characteristics are shown in Table 2, 3, and 4 .

\footnotetext{
*Corresponding author: brahim.benaji@um5.ac.ma/lashab.hager@gmail.com
} 


\subsection{Quality Control}

Before considering the effect of AS, a dry state measurement of the minimum breaking load (MBL) of the selected suture is taken at $\mathrm{T}_{0}$.

\subsection{Oral environment simulation}

The SAGF type of AS (Artificial Saliva Gal Fovet), was prepared according to the protocol of Gal, and maintained at a pH between 5.9 and 7.5 in an incubator at $37^{\circ} \mathrm{C}[4]$.

Artificial saliva was prepared by mixing the following chemicals (Table1) in one liter of distilled water:

Table 1. The components of artificial saliva type SAFG

\begin{tabular}{|c|c|}
\hline \multicolumn{2}{|c|}{ Artificial saliva medium } \\
\hline Reagents & $\begin{array}{c}\text { Concentration } \\
\mathrm{mg} / \mathrm{L}\end{array}$ \\
\hline Sodium Chloride $(\mathrm{NaCl})$ & 125.6 \\
\hline Potassium chloride $(\mathrm{KCl})$ & 963.9 \\
\hline $\begin{array}{l}\text { Potassium Thiocyanate } \\
\text { (KSCN) }\end{array}$ & 189.2 \\
\hline $\begin{array}{l}\text { Potassium dihydrogenophosphate } \\
\left(\mathrm{KH}_{2} \mathrm{PO}_{4}\right)\end{array}$ & 654.5 \\
\hline $\begin{array}{l}\text { Sodium sulfate decahydrate } \\
\left(\mathrm{Na}_{2} \mathrm{SO}_{4}, 10 \mathrm{H}_{2} \mathrm{O}\right)\end{array}$ & 763.2 \\
\hline Ammonium Chloride $\left(\mathrm{NH}_{4} \mathrm{Cl}\right)$ & 178.0 \\
\hline $\begin{array}{l}\text { Calcium Chloride Dihydrate } \\
\left(\mathrm{CaC}_{12}, 2 \mathrm{H}_{2} \mathrm{O}\right)\end{array}$ & 227.8 \\
\hline $\begin{array}{l}\text { Sodium hydrogen carbonate } \\
\left(\mathrm{NaHCO}_{3}\right)\end{array}$ & 630.8 \\
\hline Urea & 200.0 \\
\hline
\end{tabular}

\subsection{Tensile strength}

The "LF plus" traction machine, manufactured by LOYD in the UK. LFplus, is applied systematically to medical devices, determining the tensile strength (MBL) of specimens prepared from the samples tested. The device is controlled by control software: NEXYGEN plus, version 2.1.

\subsection{Experimental protocol}

Suture samples are prepared in the same way for all tests according to the requirements of Eur.Ph.9.5[5]. The suture is cut so as to have a length of $22.5 \mathrm{~cm}$ with a simple knot at an equal distance between the attachment points.

They are placed in contact with the AS simulating the oral environment and are maintained for a determined incubation time. The tensile strength of the different samples is tested over time at specific points:

- Pre-immersion (Dry state) $\left(=\mathrm{T}_{0}\right)$,

- Post-immersion (in AS) T = 1h, 1, 3, 7, 10, 14, 21, and 28 Days, depending on the metric diameter.

The tensile strength test was used according to the protocol of the Eur.Ph.9.5. It corresponds to the necessary tensile force to break a wire carrying a simple knot. The measurement for each point fixed in time is carried out 5 times following the recommendations of the Eur.Ph.9.5. The force required to break the wire corresponds to the average of the 5 measurements (MBL).

\subsection{Statistical analyzes}

A descriptive statistical analysis was performed in the present study. The measurement results are presented as the mean \pm standard deviation. Significance was assessed at a level of 5\%.

\section{Results}

Macroscopic examination at the end of the study for each fixed point in time, showed that all the threads were intact. In the tensile test, its wires individually demonstrated a breaking point after being measured on the LF plus tensile device.

\subsection{Quality Control}

The results of Table 2, indicate that each measured value meets the acceptance criteria defined by the Eur.Ph.9.5.

Table 2. Average of the minimum breaking load at $T_{0}$ (MBLT ${ }_{0}$ ) of the suture according to the standards of the

\begin{tabular}{|c|c|c|c|c|c|}
\hline \multicolumn{6}{|c|}{ Eur.Ph.9.5 } \\
\hline 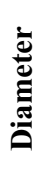 & 苍 & 总 & 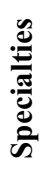 & 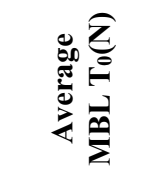 & 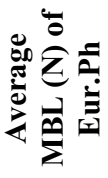 \\
\hline \multirow{3}{*}{$\stackrel{n}{-}$} & \multirow{4}{*}{$\begin{array}{c}\text { Not } \\
\text { absorba } \\
\text { ble }\end{array}$} & \multirow{3}{*}{ 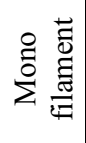 } & 1 & $9.75 \pm 1.99$ & \multirow{3}{*}{5.0} \\
\hline & & & 2 & $9.19 \pm 0.67$ & \\
\hline & & & 3 & $10.73 \pm 0.85$ & \\
\hline \multirow{3}{*}{ t } & & \multirow{3}{*}{$\sum \frac{\vec{\Xi}}{\stackrel{\Xi}{\Xi}}$} & 4 & $51.98 \pm 2.98$ & 27.0 \\
\hline & Absob- & & 5 & $67.02 \pm 2.36$ & \multirow{2}{*}{50.8} \\
\hline & bable & & 6 & $72.34 \pm 4.35$ & \\
\hline
\end{tabular}

In view of its results, our dry suture (Preimmersion $=\mathrm{MBLT}_{0}$ ) therefore comply with the requirements of the latter, we can then continue the study and make a valid conclusion about the postimmersion test (MBLTx).

\subsection{Post-immersion}

After 10 days of immersion (Figure 1) in SAGF type AS, the Polypropylene suture significantly (5\%) maintained its initial strength compared to the other two Polyamide sutures.

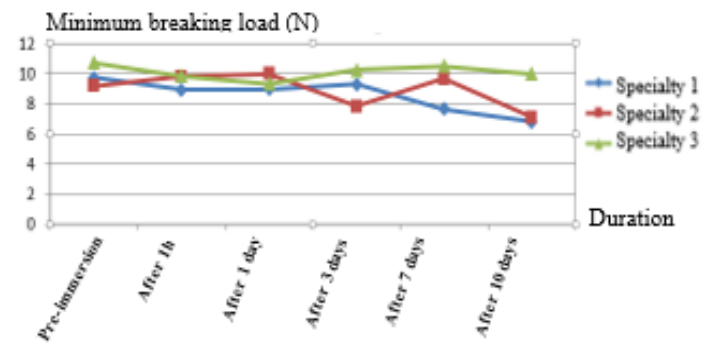

Fig 1. Variation of the minimum breaking load of 1.5 metric diameter suture 
The latter showed a similar behavior between them, with a significant difference $(p<0.05)$ expressed by an initial resistance percentage of $69 \%$ and $77 \%$ respectively for Specialty 1 and Specialty 2 (Table3).

Table 3. Average MBLTx of 1.5 metric diameter suture in $\mathrm{AS}\left[\%=\mathrm{MBLTx} / \mathrm{MBLT}_{0}\right]$

\begin{tabular}{|c|c|c|}
\hline Material & $\begin{array}{c}\text { Contact duration } \\
\text { (Postimmersion) }\end{array}$ & $\begin{array}{c}\text { Average of } \\
\text { MBL Tx (N) } \\
{\left[\% \text { of } T_{0}\right]}\end{array}$ \\
\hline \multirow{6}{*}{$\begin{array}{l}\text { Specialty } 1 \\
\text { (Polyamide) }\end{array}$} & $\begin{array}{l}\text { Preimmersion } \\
\left(\mathrm{MBL}_{\mathrm{T} 0}\right)\end{array}$ & $\begin{array}{l}9.75 \pm 1.99 \\
{[100.00 \%]}\end{array}$ \\
\hline & 1 hour & $\begin{array}{c}8.92 \pm 0.90 \\
{[91.48 \%]}\end{array}$ \\
\hline & 1 day & $\begin{array}{c}8.95 \pm 1.30 \\
{[91.79 \%]}\end{array}$ \\
\hline & 3 days & $\begin{array}{c}9.31 \pm 0.75 \\
{[95.48 \%]}\end{array}$ \\
\hline & 7 days & $\begin{array}{c}7.63 \pm 0.89 \\
{[78.25 \%]}\end{array}$ \\
\hline & 10 days & $\begin{array}{c}6.80 \pm 0.78 \\
{[69.74 \%]}\end{array}$ \\
\hline \multirow{6}{*}{$\begin{array}{l}\text { Specialty } 2 \\
\text { (Polyamide) }\end{array}$} & $\begin{array}{l}\text { Preimmersion } \\
\left(\mathrm{MBL}_{\mathrm{T} 0}\right)\end{array}$ & $\begin{array}{l}9.19 \pm 0.67 \\
{[100.00 \%]}\end{array}$ \\
\hline & 1 hour & $\begin{array}{l}9.80 \pm 1.52 \\
{[106.63 \%]}\end{array}$ \\
\hline & 1 day & $\begin{array}{l}9.78 \pm 0.95 \\
{[106.42 \%]}\end{array}$ \\
\hline & 3 days & $\begin{array}{c}7.83 \pm 0.92 \\
{[85.20 \%}\end{array}$ \\
\hline & 7 days & $\begin{array}{l}9.68 \pm 0.45 \\
{[105.33 \%]}\end{array}$ \\
\hline & 10 days & $\begin{array}{c}7.11 \pm 1.36 \\
{[77.36 \%]}\end{array}$ \\
\hline \multirow{6}{*}{$\begin{array}{c}\text { Specialty } 3 \\
\text { (Polypropolene) }\end{array}$} & $\begin{array}{l}\text { Preimmersion } \\
\left(\mathrm{MBL}_{\mathrm{T} 0}\right)\end{array}$ & $\begin{array}{c}10.73 \pm 0.85 \\
{[100.0 \%]} \\
\end{array}$ \\
\hline & 1 hour & $\begin{array}{c}9.86 \pm 0.64 \\
{[91.89 \%]}\end{array}$ \\
\hline & 1 day & $\begin{array}{c}9.34 \pm 0.48 \\
{[87.04 \%]}\end{array}$ \\
\hline & 3 days & $\begin{array}{c}10.25 \pm 0.54 \\
{[95.52 \%]}\end{array}$ \\
\hline & 7 days & $\begin{array}{c}10.49 \pm 0.73 \\
{[97.7 \%]} \\
\end{array}$ \\
\hline & 10 days & $\begin{array}{c}9.98 \pm 0.66 \\
{[93.01 \%]}\end{array}$ \\
\hline
\end{tabular}

The results reported in Table 4 and Figure 2 show that:

- Before immersion, the minimum breaking load of Polyglactin 910 suture is greater than that of PGA suture.

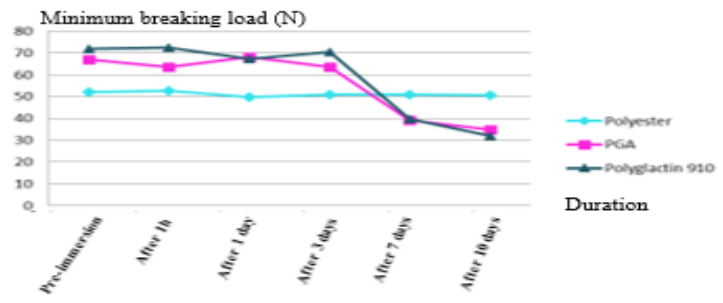

Fig2. Variation of the minimum breaking load of 4 metric diameter suture
- From the $7^{\text {th }}$ day, both sutures showed a significant decrease in their tensile strength. Around the $21^{\text {st }}$ day, the PGA suture maintained its MBL (19.71\%) compared to the Polyglactin 910 suture (7.98\%).

For the Polyester suture, we can see that there is no significant difference between the pre and postimmersion, reflected in the stability of the minimum breaking load measured throughout the incubation period.

Table 4. Average MBLTx of metric diameter 4 sutures in AS $\left[\%=\right.$ MBLTx $\left./ \mathrm{MBLT}_{0}\right]$

\begin{tabular}{|c|c|c|}
\hline Material & $\begin{array}{l}\text { Contact duration } \\
\text { (Postimmersion) }\end{array}$ & $\begin{array}{c}\text { Average of } \\
\text { MBL Tx (N) } \\
{\left[\% \text { of } T_{0}\right]}\end{array}$ \\
\hline \multirow{9}{*}{$\begin{array}{l}\text { Specialty } 4 \\
\text { (PGA) }\end{array}$} & $\begin{array}{l}\text { Preimmersion } \\
\left(\mathrm{MBL}_{\mathrm{T} 0}\right)\end{array}$ & $\begin{array}{c}67.02 \pm 2.36 \\
{[100.00 \%]}\end{array}$ \\
\hline & 1 hour & $\begin{array}{c}63.46 \pm 3.18 \\
{[94.68 \%]}\end{array}$ \\
\hline & 1 day & $\begin{array}{c}67.99 \pm 5.04 \\
{[101.44 \%]}\end{array}$ \\
\hline & 3 days & $\begin{array}{c}63.48 \pm 3.88 \\
{[94.71 \%]}\end{array}$ \\
\hline & 7 days & $\begin{array}{c}39.11 \pm 1.59 \\
{[58.35 \%]}\end{array}$ \\
\hline & 10 days & $\begin{array}{c}34.99 \pm 1.06 \\
{[52.20 \%]}\end{array}$ \\
\hline & 14 days & $\begin{array}{c}23.65 \pm 1.57 \\
{[35.28 \%]}\end{array}$ \\
\hline & 21 days & $\begin{array}{c}13.21 \pm 1.38 \\
{[19.71 \%]}\end{array}$ \\
\hline & 28 days & $0.00[0.00 \%]$ \\
\hline \multirow{9}{*}{$\begin{array}{c}\text { Specialty } 5 \\
\text { (Poyglactin910) }\end{array}$} & $\begin{array}{l}\text { Preimmersion } \\
\left(\mathrm{MBL}_{\mathrm{T} 0}\right)\end{array}$ & $\begin{array}{c}72.51 \pm 4.35 \\
{[100.00 \%]}\end{array}$ \\
\hline & 1 hour & $\begin{array}{c}72.51 \pm 0.37 \\
{[101.23 \%]} \\
\end{array}$ \\
\hline & 1 day & $\begin{array}{c}67.29 \pm 2.22 \\
{[93.01 \%]}\end{array}$ \\
\hline & 3 days & $\begin{array}{c}70.39 \pm 2.73 \\
{[97.30 \%]}\end{array}$ \\
\hline & 7 days & $\begin{array}{c}39.64 \pm 1.99 \\
{[54.79 \%]}\end{array}$ \\
\hline & 10 days & $\begin{array}{c}31.93 \pm 1.04 \\
{[44.13 \%]}\end{array}$ \\
\hline & 14 days & $\begin{array}{c}20.28 \pm 1.73 \\
{[28.03 \%]}\end{array}$ \\
\hline & 21 days & $\begin{array}{c}5.73 \pm 0.34 \\
{[7.92 \%]}\end{array}$ \\
\hline & 28 days & $0.00[0.00 \%]$ \\
\hline \multirow{6}{*}{$\begin{array}{l}\text { Specialty } 6 \\
\text { (Polyester) }\end{array}$} & $\begin{array}{l}\text { Preimmersion } \\
\left(\mathrm{MBL}_{\mathrm{T} 0}\right)\end{array}$ & $\begin{array}{c}51.98 \pm 2.98 \\
{[100.0 \%]} \\
\end{array}$ \\
\hline & 1 hour & $\begin{array}{c}52.55 \pm 4.24 \\
{[101.09 \%]}\end{array}$ \\
\hline & 1 day & $\begin{array}{c}49.89 \pm 2.92 \\
{[95.97 \%]}\end{array}$ \\
\hline & 3 days & $\begin{array}{c}50.97 \pm 2.48 \\
{[98.05 \%]}\end{array}$ \\
\hline & 7 days & $\begin{array}{c}50.97 \pm 1.86 \\
{[98.05 \%]}\end{array}$ \\
\hline & 10 days & $\begin{array}{c}50.57 \pm 4.86 \\
{[97.28 \%]}\end{array}$ \\
\hline
\end{tabular}




\section{Discussion}

The sutures marketed are generally indicated for all surgical specialtys, rarely the indication specified [2]. Of course, the behavior of the material constituting the suture cannot be the same at the different implantation sites. According to the results obtained, we can say that during an oral surgical intervention requiring an implant for a period of at least 10 days; the choice will be the Polypropylene suture compared to the Polyamide suture, since it maintains its initial resistance better. This can be explained by the fact that Polypropylene has, most of the time has sufficient strength to cope with stressors $[4,6]$, despite the fact that it can occasionally break $[7,8]$.

Our results are in agreement with the study by Chu and al. [9] who reported that Polypropylene maintained its initial strength stable in a $\mathrm{pH} 7.4$ solution during the same incubation period. Polyamide suture is widely used even if it is rigid, owing to its physical qualities and its lower purchase cost. The drop in the MBL of Polyamide suture (Specialty 1 and 2) after 10 days of immersion at 37 ${ }^{\circ} \mathrm{C}$, can be explained by the fact that the Polyamide, well qualified as non-absorbable, undergoes gradual hydrolysis in vivo. Which causes a loss of its resistance over time of about $10 \%$ to $20 \%$ per year [10]. In our study, the loss of resistance is much more important, reaches an average of $28 \%$ after 10 days. This difference can be explained by the fact that the conditions in vivo are stable compared to our experimental conditions in vitro. As for the difference in strength between the two Polyamide specialties, it could be explained by the difference in their manufacturing process.

In view of our results and those of the literature, Polypropylene suture is the best suited, compared to Polyamide suture, for delicate surgical operations.

Clinically, most absorbable sutures are made of biodegradable materials, of which PGA is the most important material since all biodegradable polymers are derived from PGA [11]. Before the $7^{\text {th }}$ day of incubation, the MBL of the PGA suture (94.71\%) was lower than that of the Polyglactin 910 suture (98.11\%). The result is normal since PGA is a polymer of Glycolic Acid monomer which hydrolyzes on contact with fluids [12]. Polyglactin 910 is a copolymer composed of $90 \%$ PGA and 10\% Polylactic Acid. The presence of the latter increases the hydrophobicity of the material. This initially slows down the penetration of water into the suture and consequently slows down the phenomenon of hydrolysis and therefore that of the resorption of the suture. [13]. From the $7^{\text {th }}$ day the MBL of the PGA suture decreased significantly with a greater frequency since the contact surface between the material and the fluid (AS) became more important, following the degradation of certain polymers. At the end of the $21^{\text {st }}$ day, there is a decrease in the load of the Polyglactin 910 suture $(7.98 \%)$ which remains lower than that of the PGA suture (19.71\%). This decrease is explained by the disappearance of the Lactic Acid molecules, which creates an empty space facilitating the penetration of water into the filaments and consequently accelerates the resorption of the mass of the residual suture [13]. This character gives Polyglactin 910 strength allowing it to maintain its resistance for a longer time and on the other hand a faster mass resorption. The work of Sujeet et al, using a mixture of AS and human serum, with proportions of $50 \%$, showed that PGA and Polyglactin 910 maintained their resistance stable respectively during the first 3 and 7 days. In the $14^{\text {th }}$ day, the MBL was canceled [14]. In addition, the study by Moser et al, using a Ringer Lactate solution showed that the strength of the PGA suture was maintained for 13 days [12]. The difference between our study and those of Sujeet et al., And Moser et al., Could be explained respectively by the type of the immersion solution [14], and by the incubation step at $37^{\circ} \mathrm{C}$.

The mixing of saliva and human serum appears to improve suture degradation, resulting in a significant decrease in tensile strength.

Regarding the non-absorbable Polyester suture, its minimum breaking load is maintained throughout the incubation period. In the literature, Polyesters are particularly stable. They are described as materials which exhibit very good breaking strength compared to polyamides.

\section{Conclusion}

In the light of the obtained results, it was found that in contact with AS the initial resistance of Polypropylene is maintained compared to that of Polyamide, and that of Polyester is stable. During the first 7 days Polyglactin 910 maintains its initial resistance compared to PGA, while the latter maintains it better from the $7^{\text {th }}$ day of immersion.

\section{Acknowledgments}

The authors gratefully acknowledge the support provided by the national drug control laboratory, especially the medical devices and physico-chemical services team for carrying out this work.

The authors would also like to express their sincere thanks to Professor Fouzia Lamkhanter, English studies Department, faculty of Letters and 
Humanities, Ain Chock, Hassan II University of Casablanca, for proofreading and editing the first version of this article.

\section{Reference}

1. J. Gaudy, C. Bilweis, B. Lazaroo et al. CdP. Incisions et sutures 210 (2007)

2. Instruction d'utilisation Assufil ${ }^{\circ}$, (2012)

3. Pharmacopée Européenne, Monographies relatives aux "Fils chirurgicaux pour usage humain". Edition 9.5 (2018)

4. P.B. Dobrin. J Vasc Surg. Polypropylene suture stresses after closure of longitudinal arteriotomy 7 423-428 (1988)

5. P. C. Fenoll, J.V. Munoz Montagud, V.Sanchiz, Et al. Rev. Esp. Enferm. Dig. Unstimulated Salivary flow rate, $p H$ and buffer capacity of saliva in healthy volunteers. 96(11) 773-783 (2004)

6. R.W. Landymore, A.E. Marble, C.A. Cameron. Am J Surg. Effect of force on anastomotic suture line disruption after carotid arteriotomy. 154 309-312 (1987)

7. P. Tarut, P. Florin, J. Courtin. Bull Soc Ophtal Fr Les complications dues au Prolene. 81 601-603 (1981)

8. T.R. Calhoun, C.M. Kitten. J Vasc Surg. Polypropylene suture-Is it safe? 4 98- 100 (1986)

9. C.C. Chu, G. Moncrief. Ann Surg. An in vitro evaluation of the stability of mechanical properties of surgical suture materials in various pH conditions 198 223-228 (1983)

10. F. Dubrana, Ph. Pasquier, W. Hu, et al. Springer. Ligatures et sutures chirurgicales. 387 (2011)

11. T.W. Huang, P.W. Cheng, Y.H. Chan, et al. Otolaryngol Head Neck Surg. Clinical and biomechanical analyses to select a suture material for uvulopalatopharyngeal surgery. 143 655-61 (2010)

12. J.B. Moser, E.P. Lautenschlager, B.J. Horbal, J Dent Res. Mechanical properties of polyglycolic acid sutures in oral surgery. 53 804-808 (1974)

13. J. Bilweis. Laboratoires Ethicon ${ }^{\circledR}$ Ligatures et sutures chirurgicales. 11éme édition 130 (1993)

14. V.K. Sujeet, V. Ranganath, S.N. Ashish J Periodontol. Evaluation of tensile strength of surgical synthetic absorbable suture materials: an in vitro study. 43(3) 